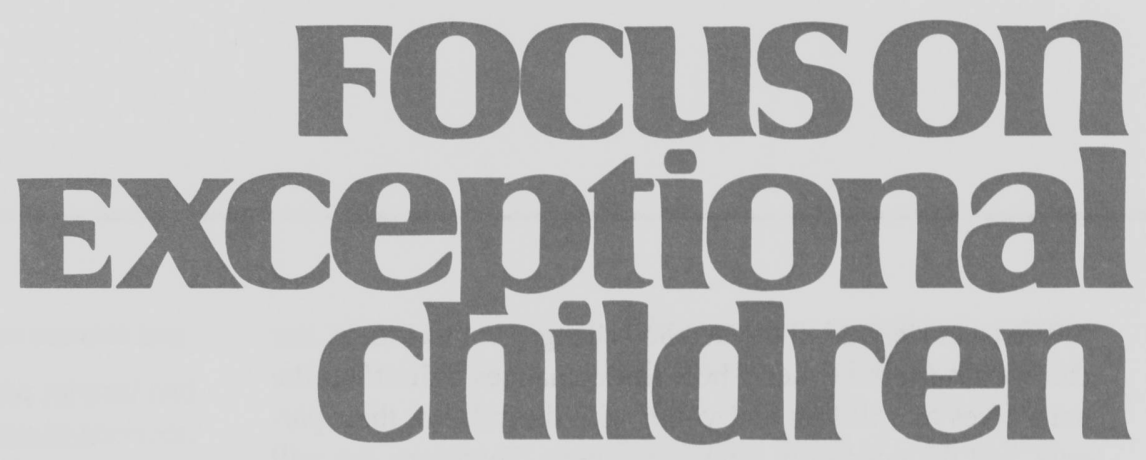

\title{
The IDEA Amendments of 1997: Implications for Special and General Education Teachers, Administrators, and Teacher Trainers
}

\author{
Mitchell L. Yell and James G. Shriner
}

On June 4, 1997, President Clinton signed the Individuals with Disabilities Education Act Amendments of 1997, PL 105-17, into law. This law amended and reauthorized the Individuals with Disabilities Act (IDEA). The 1997 amendments added a number of major provisions to the IDEA that will result in substantial changes in the education of students in special education, as well as the roles of administrators, general educators, special educators, and teacher trainers.

In passing the amendments, Congress noted that the IDEA had been successful in ensuring access to a free appropriate public education and improving educational results for students with disabilities. Nevertheless, Congress indicated that the implementation of the IDEA had been impeded by low expectations for students, an insufficient focus on translating research to practice, and too much emphasis placed on procedural paperwork tied to legal requirements and not focused on teaching and learning, and better student outcomes.

To improve the IDEA, Congress passed the most significant amendments to the law since the original passage in 1975. These amendments were seen as the next step in providing special education and related services by ensuring that students with disabilities would receive a quality public education emphasizing the improvement of student performance.

Congress viewed the reauthorization process as an opportunity to strengthen and improve the IDEA by:

— strengthening the role of parents;

— ensuring access to the general education curriculum and reforms;

— focusing on teaching and learning while reducing unnecessary paperwork requirements;

- assisting education agencies in addressing the costs of improving special education and related services to children with disabilities;

— giving increased attention to racial, ethnic, and linguistic diversity to prevent inappropriate identification and mislabeling;

- ensuring that schools are safe and conducive to learning; and

- encouraging parents and educators to work out their differences using nonadversarial means. (Senate Report 1997, p. 5)

Mitchell Yell is affiliated with the University of South Carolina, and James Shriner with the University of Illinois at Urbana-Champaign. 
We cannot cover all the detailed changes in this article, nor can we determine exactly how these changes will affect the daily lives of children and youth with disabilities, their parents, and the educators who serve them. Therefore, we will focus on areas of change to the IDEA that concern special educators most directly, including changes in the individualized education program (IEP) process, discipline of students with disabilities, accountability and procedural safeguards. We offer our interpretations of how these changes may affect the education of students with disabilities and set forth recommendations to teachers, administrators, and teacher trainers in meeting the requirements of the IDEA Amendments of 1997.

\section{RESTRUCTURING OF THE IDEA}

Originally, the IDEA was divided into nine parts or subchapters. In the IDEA amendments of 1997, the law was restructured into four parts shown in Table 1. Subchapters one

\section{FOCuson Exceptional chilaren}

ISSN 0015-511X FOCUS ON EXCEPTIONAL CHILDREN (USPS 203-360) is published monthly except June, July, and August as a service to teachers, special educators, curriculum specialists, administrators, and those concerned with the special education of exceptional children. This publication is annotated and indexed by the ERIC Clearinghouse on Handicapped and Gifted Children for publication in the monthly Current Index to Journals in Education (CIJE) and the quarterly index, Exceptional Children Education Resources (ECER). The full text of Focus on Exceptional Children is also available in the electronic versions of the Education Index. It is also available in microfilm from Xerox University Microfilms, Ann Arbor, MI. Subscription rates: Individual, \$30 per year; institutions, \$40 per year. Copyright (C) 1997, Love Publishing Company. All rights reserved. Reproduction in whole or part without written permission is prohibited. Printed in the United States of America. Periodicals postage is paid at Denver, Colorado. POSTMASTER: Send address changes to:

$$
\begin{gathered}
\text { Love Publishing Company } \\
\text { Executive and Editorial Office } \\
\text { P.O. Box } 22353 \\
\text { Denver, Colorado } 80222 \\
\text { Telephone (303) } 757-2579
\end{gathered}
$$

Edward L. Meyen

University of Kansas

Glenn A. Vergason Georgia State University

Richard J. Whelan University of Kansas Medical Center

\begin{abstract}
Stanley F. Love
Publisher
\end{abstract}

Thomas Love

Associate Editor

and two are referred to as Part A and Part B, respectively.

- Part A contains the general provisions of the law (e.g., definitions).

- Part B details the grant program that requires states receiving federal assistance under the IDEA to ensure a free appropriate public education to all qualified children and youth with disabilities residing in a state. Part $\mathrm{B}$ also contains the procedural safeguards designed to protect the interests of children and youth with disabilities.

- Part C extends Part B protections to infants and toddlers with disabilities and strengthens incentives for states to provide services to infants and toddlers (birth to age 3 ). Part $\mathrm{C}$ (originally Part $\mathrm{H}$ ) was added to the IDEA in 1986 with the passage of PL 99-457 (IDEA, 20 U.S.C. $\S 1471-1485)$.

- Part D is composed of the discretionary or support programs. These programs have been enacted to address various concerns regarding the education of students with disabilities. Part D contains provisions regarding state improvement grants for educating students with disabilities, research, personnel preparation, technical assistance, dissemination of information, parent training, and technology development.

\section{TABLE 1}

IDEA Amendments of 1997: Framework of the IDEA

Part Title Content

Part A General Provisions

Part B Assistance for education of all children with disabilities

Part C Infants and toddlers with disabilities

Part D National activities to improve education of children with disabilities

\author{
- Definitions, findings, \\ and purposes \\ - SEA \& LEA eligibility \\ - Special education \\ services: evaluations, \\ eligibility, IEPs, \\ placements, and \\ procedural safeguards \\ - Programs for infants \\ and toddlers \\ - Discretionary or \\ support programs: \\ state improvement \\ grants, research, \\ personnel preparation, \\ technical assistance, \\ support, dissemination \\ of information, and \\ technology
}




\section{EVALUATION}

In a sense, special education "begins" with the referral and evaluation process that may lead to the provision of services. These activities have been the central concern for many people--educators and parents alike. As such, evaluation is a useful beginning point for our description of the changes found in IDEA. Table 2 contains the IDEA requirements regarding evaluations.

\section{TABLE 2}

IDEA Requirements: Evaluations, Eligibility Determinations, Section 614

Key Points
Consent or

Refusal

Eligibility for Special Education

Reevaluations

Assessment Tools

Instruments \& Tests

\author{
Explanation \\ - Informed consent required before \\ evaluation \\ - If parents refuse consent, the school \\ may use mediation or due process \\ procedures to secure permission to \\ evaluate. \\ - Consent is not required for \\ reevaluation if parents fail to \\ respond to reasonable attempts. \\ - Consent for evaluation is not \\ consent for placement or related \\ services. \\ - Child can not be eligible because \\ of a lack of instruction in reading \\ or math or because of limited \\ English proficiency. \\ - At least every three years. \\ - Conducted if conditions warrant a \\ reevaluation or if the parents or \\ teacher requests. \\ - Additional data need not be \\ collected, but parents must be \\ informed of the reasons for this \\ decision and their option to request \\ assessments. \\ - The LEA is required to use a variety \\ of assessment tools to gather \\ relevant functional and develop- \\ mental information about the \\ student, including data about \\ involvement in the general \\ curriculum. \\ - Existing data must be considered. \\ - Technically sound instruments are \\ required when assessing cognitive, \\ behavioral, physical, or develop- \\ mental factors.
}

\section{- LEAs must ensure that tests are not discriminatory (racially or culturally) and are provided in child's native language or mode of communica- tion.}

The formal assessment and evaluation procedures of IDEA are intended to ensure that: (a) special education services are provided to children and youth who demonstrate the need for such services, (b) decisions for service provision are fair and defensible, and (c) all requirements for evaluations are implemented consistently in all districts and states and monitored for appropriateness and compliance (Shriner \& Spicuzza, 1995). Evaluation procedures of PL 105-17 essentially reflect current policy contained in the existing law and accompanying regulations. The new law will codify all requirements in one section (Sec 614).

A few important changes in evaluation procedures are attempts to clarify parents' rights to information. First, in regard to the requirement of parents' consent for evaluation of their child, the new version puts consent in the legislative language and stresses that consent for evaluation is not consent for placement of a child. Furthermore, parental consent now is required for reevaluations unless the school can determine that the parents failed to respond to reasonable attempts to obtain their consent. A key addition to the procedures requires that all evaluations include information about the student's involvement and progress in the general curriculum or, for preschoolers, in appropriate activities. This information, in addition to existing rules that prior notice and explanations of all evaluation procedures, tests, records, and reports be provided, assures parents of a more complete picture of what is happening for their child.

Great concern over the rising numbers of students classified as learning disabled led to the committee to include a new provision in Sec. 614 (b)(5). This special rule prohibits eligibility decisions to be made because the student has had a lack of instruction or because he or she has limited English proficiency. The provision is intended to force considerations of all factors that might be affecting a student's performance and reduce the number of students who are improperly placed in special education. The committee anticipates that this provision will cause schools to focus greater attention on mathematics and reading in the early grades (Senate Report, 1997).

The reevaluation process has been streamlined in PL $105-17$. The 3 -year reevaluation was extremely cumbersome because it usually involved extensive assessment of the student. Sometimes students were put through a complete as- 
sessment battery for no reason other than to satisfy report requirements. Under the new law a 3-year re-evaluation may rely on existing information and assessments. If the LEA believes that no additional data are needed and notifies the parent of this option, the reevaluation can be conducted without doing any new assessments. The parents must concur with this plan, or the school must demonstrate that the parents did not respond to notifications for consent to carry out a no-assessment evaluation. Alternatively, the parent or the school may believe it is best to conduct an assessment in any or all areas of development if this data would provide useful information about how to best teach the child. In this regard, the reevaluation process is more purposeful-seeking to assess only when there are valid reasons to do so.

\section{THE INDIVIDUALIZED EDUCATION PROGRAM}

Congress believed that the IDEA had been extremely successful in improving students' access to public schools, and that the critical issue in 1997 was to improve the performance and educational achievement of students with disabilities. To this end, Congress mandated a number of changes to the individualized education program (IEP). The major change is that the entire IEP process now is focused on student participation in the general education curriculum. Table 3 contains the new IDEA requirements regarding the IEP.

\section{TABLE 3}

IDEA Requirements:

Individualized Educational Programs and Placement

\section{Key Points}

Required

Participants

Sec. 614

(d)(1)(B)

Development Considerations Sec. 614 (d)(3)

\section{Explanation}

- Parent

- Regular education teacher

- Special education teacher

- LEA representative knowledgeable about general curriculum

- Person who can interpret the instructional implications of evaluation results (may be one of the above members)

- The team should consider: child's strengths, parents' concerns, most recent evaluation, language needs of LEP children, child's communication needs, and assistive technology; braille instruction when appropriate
Placement

Decisions

Content

Sec. 614

(d)(1)(A)

Transition

Services

Sec. 614

$(d)(1)(A)(v i i)$

Review

Schedules

Sec. $614(d)(4)$
- When behavior is an issue, strategies and supports to address that behavior

- Regular educators will participate in all above decisions.

- The IEP team will make most decisions, but when they don't, LEAs must "ensure" parent participation.

- Present levels of performance (including how disability affects involvement and progress in general curriculum)

- Measurable annual goals including benchmarks or short-term objectives (related to meeting the child's needs to enable him or her to be involved in the general curriculum and other needs resulting from the disability)

- Special education and other services, supplementary aids, any program modifications or support for school personnel necessary for student to meet annual goals

- Explanation of the extent to which child will not participate in general education

- Individual modifications in administration of achievement tests, or explanation of why this is not appropriate and how child will be assessed

- Projected date for beginning services, anticipated service frequency, location, and duration

- Measures of progress toward annual goals and how parents will be kept informed of progress

- Beginning at age 14 and updated annually, statement of transition service needs that focus on student's existing program or courses

- Beginning at age 16, specific transition services including interagency responsibilities

- Beginning at least 1 year before the student reaches the age of majority, student informed of his or her rights

- At least once a year by IEP team, using the following criteria: any lack of progress toward annual goals and in the general 
curriculum, results of any reevaluation, information about child provided by parents, new information about child's anticipated needs.

\section{IEP Requirements}

The IEP will remain the cornerstone of services for all children and youth with disabilities. The accompanying committee report emphasizes the intent of Congress to ensure that the "IEP process . . . is devoted to determining the needs of the child and planning for the child's education with the parents and school personnel" (Senate Report, 1997, p. 28).

\section{Participants}

Included in Table 3 is a listing of the people to be involved as team participants (e.g., parents and special educators). The requirement that a general education teacher be involved if a student is participating or may participate in the general education environment reflects the emphasis on general curricular involvement found throughout IDEA. Most children with disabilities are in the mainstream for at least part of the day, so general educators usually will be involved in the overall IEP process. The general education teacher, however, may not need to be involved in "all aspects of the IEP team's work" (Senate Report, 1997, p. 26). Some individual tasks (e.g., related services coordination) do not require the participation of a general education teacher.

Another person who must participate is a representative of the local school who has (a) authority to provide, or supervise the provision of, specially designed instruction to meet the needs of children with disabilities, (b) knowledge of the general curriculum, and (c) knowledge of the resources of the LEA. A psychologist is not specified as a required participant under the new law. Rather, a person who can interpret instructional implications of evaluation results is needed. This could be a teacher or the LEA representative described above. Special services personnel, or persons with specific expertise, such as specialists in reading, may be involved when appropriate. School nurses are mentioned specifically in the committee report as likely IEP team members as schools assume greater responsibility for educationally related health-care needs and their associated costs.

\section{Annual Goals and Benchmarks}

Further changes to the IEP content require the development of measurable annual goals, including benchmarks or short-term objectives, that will enable parents and educators to accurately determine a student's progress. The goals are written to reflect students' needs to enable them to be involved in and progress in the general education curriculum and other educational needs related to the disability. As before, these goals should address both academic and nonacademic concerns and be based on the student's current level of educational and behavioral performance.

Goals and objectives, correctly written, enable the teachers and parents to monitor a student's progress in a special education program and make educational adjustments when necessary (Deno, 1992). The 1997 amendments emphasize accurate measuring and reporting of a student's progress toward the annual goals. Annual goals are projections the team makes regarding the student's progress in one school year. Benchmarks or short-term objectives are written for each annual goal. Congress intended that short-term goals be, in effect, benchmarks. Congress viewed the requirement of measurable annual goals and benchmarks or short-term objectives as "crucial to the success of the IEP" (Senate Report, 1997, p. 25). If a student achieves the benchmarks or short-term objectives, he or she should achieve the annual goals also. The benchmarks or short-term objectives describe what a student is expected to accomplish in a given time period.

An accountability provision built into the annual goalbenchmark strategy reflects Congress' strong feelings about this issue. The new IDEA requires that the child's parents be informed of the child's progress toward annual goals (via benchmarks) as often as parents of nondisabled children are informed of their children's progress. For example, if a school normally sends home interim marking period reports at $41 / 2$ weeks and report cards at 9 weeks for each quarter of the school year, special educators might send home IEP progress reports at the same frequency.

The committee report goes so far as to suggest a possible method of providing feedback to parents about their child's progress: an IEP report card with "check boxes or equivalent options that ... enable the parents and the special educator to review and judge ... performance on a ... multipoint continuum." (Senate Report, 1997, p. 25). Students' progress and ratings on the benchmarks might be communicated on a scale ranging from "No Progress" to "Completed." In this way, the effects of the general education, special education and related services a student receives can be evaluated in concert so the student's total school experience is considered. 


\section{Development of the IEP}

In developing the IEP, the law emphasizes again that the "purpose is to tailor the education to the child; not tailor the child to the education" (Senate Report, 1997, p. 27). Special education must be different from what the child typically would receive, and planning for this purpose must reflect this intent. Sections (614)(d)(3)(A \& B) list those "general" and "special" considerations that must be made (see Table 3 ). Categories of special considerations include: behavioral problems that impede learning, limited English proficiency (LEP), braille instruction, communication needs for children who are deaf or hard of hearing, and assistive technology.

The IDEA Amendments also specify that the IEP team is the proper forum for making placement decisions. Moreover, parents must take part in these decisions.

\section{Transition}

Transition services must be included in the IEP when the student reaches the age of 14 . The transition statements will focus on a student's courses of study (e.g., student participation in a vocational education program). Also beginning one year before the student reaches the age of majority, the IEP must include a statement that the student will be informed of his or her IDEA rights that will transfer to the student at the age of majority.

\section{Curriculum}

Consensus about the nature and content of the curriculum used in special education as reflected by the IEP has been lacking. Most teachers (55\%) believe the IEP is the student's yearly curriculum with concern for general curriculum considerations taking a backseat during instructional planning (Schrag, 1996). Previously, IEPs were to include descriptions of special education and related services, including modifications needed for students in the mainstream. The total education of the student, including the appropriate curriculum of the mainstream, was not expected to be covered (IDEA Regulations, 1992). The concern about how the IEP connects with goals, outcomes, and standards established by the district or state for its students was raised by McLaughlin and Warren (1995). Those authors noted that the IEP process and curricular reform efforts resulted in a fragmented program for students with disabilities because they (a) operated independently at the system level, and (b) IEP team meetings included little or no discussion about how one should affect the other. Although the IEP actually contains many of the essen- tial elements of standards (e.g., goals, performance levels, evaluation plans), special educators have tended to be passive observers of education reform (Shriner, Ysseldyke, \& Thurlow, 1994). The tendency has been to avoid integrating the IEP process with a thorough examination of student needs related to reform-oriented instruction most often found in the mainstream. The IDEA now essentially makes such a position illegal.

Beginning with the development process for IEPs (Sec. 614(d)(3)), active dialogue among special educators, general educators, and parents is necessary. The IEP team must include an individual who is knowledgeable about the general curriculum. If the student is, or may be, in the general education environment, a general education teacher also must be involved throughout the process (Sec 614(d)(1)(B)). The requirements have been anticipated by groups such as the $\mathrm{Na}$ tional Education Association (NEA) and the Council for Exceptional Children (CEC) and represent both an immediate opportunity and potential pitfall. On the one hand, teachers who spend the most time with the majority of students with disabilities will be involved in planning (Council for Exceptional Children, 1997). Others worry that these requirements promise only to produce excessive paperwork by adding descriptive sections to the IEP (Clymer, 1997).

\section{Logic of the "LRE of the Curriculum"}

The IEP will serve as documentation of the extent to which a student's educational program matches that provided to nondisabled students and addresses the goals and standards of the district and state. The concept of the LRE has applied mainly to the location of the student's education. The reauthorized IDEA and the supporting committee report affirm the intent of Congress to apply the logic of the LRE to the content of the education that would be provided to a student. Previously, only when the nature or severity of the disability was such that education in general education classes with the use of supplementary aids and services could not be achieved satisfactorily would removal of students with disabilities to a more restrictive setting be justified. Although this is still the case, both Sec. 612 and Sec. 614 emphasize that the general education curriculum is presumed to be the appropriate beginning point for planning an IEP for a student (Senate Report, 1997). Section 614(d)(1) uses the same logic for required components of the IEP by requiring:

a statement of the special education and related services and supplementary aids and services to be pro- 
vided to the child, or on behalf of the child, and a statement of the program modifications or supports for school personnel that will be provided for the child to be ... involved and progress in the general curriculum. (Sec. 614(d)(i)(A)(iii))

Only when participation in the general curriculum with supplementary support and services can be demonstrated as not benefiting the student should "removal" to an alternative curriculum be considered. This provision includes the concept of partial participation to varying degrees in the general curriculum (Senate Report, 1997). Therefore, participants in the IEP meeting and process must begin with the general curriculum as the preferred course of study for all students. An important new activity will be to document the information that participants use and the decision-making process involved in justifications for divergent curricular goals. These curricular decisions will be the basis for determinations of how the child is included in accountability systems.

\section{Participation in State- and District-wide Assessments}

Sec. 614(d) outlines several new requirements concerning the participation of students with disabilities in state or district-wide assessments. Increased emphasis on involvement and progress in the general curriculum is of little use without information about students' progress. The committee report accompanying IDEA specifically cites a desire to reduce the unnecessary exclusion of students with disabilities from assessments because such exclusion places severe limits on students' opportunities for postsecondary education and employment (Senate Report, 1997).

As such, where participation decisions are part of the IEP already, as is the case in many school districts, the decisionmaking process must be examined and possibly refined. Participation in assessment decisions sometimes have confounded issues of existing characteristics, supports, and accommodations with inclusion eligibility. For example, time spent in general education classes has been an often-used criterion for participation (Erikson, Thurlow, Thor, \& Seyfarth, 1996; Shriner, Gilman, Thurlow, \& Ysseldyke, 1995), yet this consideration may be a misplaced marker. Accountability for results related to the performance goals and standards necessitates that the initial decision be one of whether the student should or should not take part or all of a general state or district-wide assessment.
The IEP team must document which portions of the curriculum, and therefore which goals and standards, are relevant to each student in special education. It may be that all curricular goals are pertinent regardless of where instruction is provided. In this case, the student should take part in the general state assessment even if accommodations are needed. If the student's instruction addresses only some of the curricular goals, partial participation is indicated. In this case, the student has a modified assessment plan. If the student is working on performance goals and standards unique to his or her situation, because no portion of the curriculum is appropriate (even with modification), participation in the general assessment is not indicated. An alternate assessment (Sec. 612(a)(17)) is the appropriate course in these circumstances. A plan for how the student will be assessed must be part of the IEP.

One final note regarding participation in assessments concerns students with disabilities in interim alternate educational settings and prisons. If a student is convicted as an adult and incarcerated in an adult prison, participation in general assessments is not applicable (Section 614 (d)(6)(A)(i)). If he or she is in an interim alternative educational setting, all requirements for access and participation remain in effect (Section $615(\mathrm{k})(3)(\mathrm{B}))$.

\section{Accommodations in Assessments}

The IEP must include a statement of whatever modifications may be needed for participation in the assessments. In some districts and states many of these "new" requirements are part of the IEP process and document already. In South Carolina, most local education agencies are using state-prepared accommodation forms specific to each of the tests they use in the state-wide assessment, but the consistency with which these checklists are implemented and the detail with which decisions are documented is uncertain. States likely will be developing or revising their testing accommodation guidelines, as these also vary widely from state to state and district to district (Thurlow, Scott, \& Ysseldyke, 1995). Addenda to IEPs that document inclusion in curricular areas and assessments and that list appropriate modifications and accommodations will be new for many states. Examples of possible accommodations are included in Table 4. 
TABLE 4

\section{Examples of Accommodations for Assessments}

\begin{tabular}{|c|c|c|c|}
\hline Flexible Time & Flexible Setting & $\begin{array}{l}\text { Alternative } \\
\text { Presentation } \\
\text { Format }\end{array}$ & $\begin{array}{l}\text { Alternative } \\
\text { Response } \\
\text { Format }\end{array}$ \\
\hline Extended time & $\begin{array}{l}\text { Test alone in } \\
\text { test carrel or } \\
\text { separate room }\end{array}$ & $\begin{array}{l}\text { Braille or } \\
\text { large-print } \\
\text { edition }\end{array}$ & $\begin{array}{l}\text { Pointing to } \\
\text { response }\end{array}$ \\
\hline $\begin{array}{l}\text { Alternating } \\
\text { lengths of test } \\
\text { sections (e.g., } \\
\text { shorter and } \\
\text { longer) }\end{array}$ & $\begin{array}{l}\text { Test in small- } \\
\text { group setting }\end{array}$ & $\begin{array}{l}\text { Signing of } \\
\text { directions }\end{array}$ & $\begin{array}{l}\text { Using } \\
\text { template } \\
\text { for } \\
\text { responding }\end{array}$ \\
\hline $\begin{array}{l}\text { More frequent } \\
\text { breaks }\end{array}$ & $\begin{array}{l}\text { Test at home } \\
\text { (with account- } \\
\text { ability) }\end{array}$ & $\begin{array}{l}\text { Interpreta- } \\
\text { tion of } \\
\text { directions }\end{array}$ & $\begin{array}{l}\text { Giving } \\
\text { response } \\
\text { in sign } \\
\text { language }\end{array}$ \\
\hline \multirow{2}{*}{$\begin{array}{l}\text { Extended } \\
\text { testing } \\
\text { sessions over } \\
\text { several days }\end{array}$} & $\begin{array}{l}\text { Test in special } \\
\text { education } \\
\text { classroom }\end{array}$ & $\begin{array}{l}\text { Taped } \\
\text { directions }\end{array}$ & $\begin{array}{l}\text { Using a } \\
\text { computer }\end{array}$ \\
\hline & $\begin{array}{l}\text { Test in room } \\
\text { with special } \\
\text { lighting }\end{array}$ & $\begin{array}{l}\text { Highlighted } \\
\text { keywords }\end{array}$ & $\begin{array}{l}\text { Allow } \\
\text { answers in } \\
\text { test book }\end{array}$ \\
\hline
\end{tabular}

\section{ISSUES OF ASSESSMENT AS A MEANS OF ACCOUNTABILITY}

The IDEA seeks to build upon the improving trends of inclusion of students with disabilities in accountability systems at both the district and the state levels. Over time, students with disabilities have been participating to a greater extent in state-wide assessments (Erikson et al., 1996; Shriner et al., 1995), yet tremendous variability remains in the extent of participation from state to state. The provisions of Sec. 612 (a)(16) address this variability directly by requiring that students with disabilities be included in general state and district-wide assessments with appropriate accommodations when necessary. State education agencies (SEAs) and LEAs will be responsible for developing or revising participation guidelines not only for general assessments but for alternative assessments as well (Sec. 612(a)(17)).

The new requirement that is most likely to cause the biggest flurry of state- and district-level activity is that calling for an alternative assessment of progress for students who do not take part in the general state or district assessments (Sec. 612(a)(17)). To date, accountability for special educa- tion students' programs has not emphasized the results of schooling. Rather, we have tracked the types of services provided, numbers of students by category, and the like-all inputs for the education of students with disabilities. The IDEA puts a rather abrupt "about face" on this orientation, and states' activities soon will change dramatically. Specifically, the law says that state and local education agencies shall develop and conduct alternative assessments by July 1, 2000 .

\section{Alternate Assessment}

Neither "general assessment" nor "alternate assessment" is defined in IDEA. Typically, general state assessments have involved the use of criterion-referenced assessments or standardized norm-referenced tests. South Carolina, for example, uses a state-developed criterion-referenced test (Basic Skills Assessment Program, BSAP) and a norm-referenced test (Metropolitan Achievement Test-7th ed., MAT-7). Also, like many states, South Carolina is revising its criterion-referenced state assessment to better reflect the standards for coursework and achievement it has adopted for several content areas (e.g., language arts, mathematics, and science). Ysseldyke, Olsen, and Thurlow (1997) define alternate assessment as any "substitute way of gathering information on the performance and progress of students who do not participate in the typical state assessments used with the majority of students who attend schools" (p. 2).

Their definition is in response to the confusion surrounding the use of a similar term, alternative assessment. Alternative assessment is a generic term encompassing a variety of activities including authentic assessment, performance assessment, and portfolios (Taylor, 1997). Any or all of these could be part of what is intended by IDEA's alternate assessment requirements. Most important is the intention to ensure that all students have an opportunity to demonstrate what they have learned, whether that is by participation in the general assessment (which may, in fact, be an alternative assessment) or by some alternate process that the SEA or LEA will develop and implement. In this regard, alternate assessments are most appropriate for only a small percentage of students - most likely those with the most severe disabilities who are not working on any part of the general curriculum, and who will earn a differentiated diploma or certificate. Two states (Kentucky and Maryland) are cited often as having done the most work to develop and implement alternate assessments. Both states have used portfolios as the central means of gathering student information.

Kentucky uses an Alternate Portfolio to address a subset of 
the state's learner outcomes for students not working toward a regular diploma. Alternate portfolios contain at a minimum: (a) the students' schedule of school/work activities and routines, (b) a resume of job activities and experiences, and (c) examples of communication in the student's preferred mode (Kentucky Department of Education, 1992).

Maryland has pilot-tested the Independence Mastery Assessment Program (IMAP), for students with severe disabilities whose curriculum addresses learner outcomes different from those addressed by the state's general assessment. IMAP is portfolio-driven and measures student progress in four domains: (a) person management, (b) community functioning, (c) career vocational skills, and (d) leisure/recreation skills. IMAP portfolio entries include evidence of student communication, decision-making and academic and behavioral skills in these domains (Maryland State Department of Education, 1995).

Though a thorough discussion of alternate assessment is not the focus of this article, the IDEA has validated the principles embraced by both states:

1. All students who are part of the educational community must be part of the assessment and accountability system used to judge the effectiveness and benefit of the schools.

2. Only a small percentage of the special education population is best served by assessment via an alternate system alone.

3. The alternate assessments are planned with a set of goals and standards for performance established ahead of time.

The purpose of such assessments is to measure progress toward high expectations - exactly as is done for students in the general assessments that reflect the high standards adopted by the states.

\section{DEVELOPMENT OF PERFORMANCE GOALS AND INDICATORS}

In an effort to ensure that standard-based reforms benefit all students, the IDEA requires that SEAs establish goals for the performance of all students with disabilities. Nearly all states have developed or are developing standards for student knowledge and performance, and most use content areas (e.g., language arts, mathematics), as their organizational vehicle (American Federation of Teachers, 1996). The IDEA seeks to build upon these efforts by requiring that developed goals and indicators are consistent, to the maximum extent appropriate, with other goals and standards the states have established for the students. In report language submitted in support of the IDEA, the emphasis on increased access to the general curriculum and expectations of high standards is reiterated:

With regard to Section 612(a)(16), the committee wishes to make clear that its requirements are not intended to prevent the integration of performance goals and indicators for children with disabilities into [those] for nondisabled children, so that SEAs and LEAs can be held accountable for all children. (Senate Report, 1997, p. 16)

The National Center on Educational Outcomes (NCEO) has tracked the development of standards by states with particular interest in the inclusion of students with disabilities. Although NCEO currently is evaluating all available standards from states, very few have separate standards for students with disabilities. Michigan is a notable exception, having developed categorically specific standards for students as early as 1990 (Frey \& Lynch, 1992; Ysseldyke et al., 1997).

The IDEA does not specify exactly how the consistency of these performance goals and standards with those set for nondisabled students is to be evaluated. Shriner, Ysseldyke and Thurlow (1994) discussed alternative perspectives on standards and their use for students with disabilities. Among the possibilities presented were: (a) separate standards for special education students, (b) standards as expectations of progress across a range of performance, and (c) IEPs as standards. Each approach has advantages and disadvantages, and the IDEA language may be interpreted as seeking a combination of them all. First, the door seems to be left open to separate special education standards. The qualifier that newly developed performance goals be consistent "to the maximum extent possible" indicates the expectation that at least some of the goals and standards may be unique to special education students. Perhaps, students will be expected to meet standards in some core subjects and additional standards related to individual student needs.

In system-wide improvement standards an average performance standard is set and improvement for all students as a group is expected. This concept is similar to the average miles per gallon (mpg) standards once used in the automobile industry. Kentucky is one state that incorporates this idea in part of its standards and assessment system. All students' assessment results are included in school level averages that are used to measure progress of the system. Individual progress of students is not the focus of these activities-a position that 
Section 612 (a)(17) affirms in stating that assessments should not result in disclosure of performance results for individual students.

The IEP-as-standards approach reflects the overarching concept of "personal best" in which students are expected to achieve at progressively higher levels than they presently are achieving (Shriner et al., 1994). The IEP is the cornerstone of existing accountability efforts and likely will maintain an important role. Much of the report language accompanying the IDEA refers to the IEP process and content as critical elements in addressing the unique needs of every student to progress in the general education curriculum. The report language strengthens an inclusive philosophy insofar as there appears to be more concern that a student's total school program reflects a curriculum that is made to fit his or her needs, rather than allowing a student to be fit into a particular curriculum. Consider the following:

Once a child [is] eligible for special education, the connection between special education and related services and the child's opportunity to experience and benefit from the general curriculum should be strengthened... [Section 614 (d)(IEPs)] is intended to ensure that a child's special education and related services are in addition to and are affected by the general curriculum, not separate from it. (Senate Report, 1997, p. 22)

\section{REPORTING OF PERFORMANCE/PROGRESS/ ACCOUNTABILITY}

New requirements for reporting progress for students with disabilities are aimed at bringing the results of special education the same attention as is given to nondisabled students' progress and attainment. Although the term accountability is found only a few times in the IDEA, the committee members and policy makers clearly were thinking of accountability when the reporting requirements were written. These requirements move the status of students with disabilities one step further along what some have seen as an unwritten continuum of importance in education reform.

With reference to instructional time devoted to social results of schooling, Leone, McLaughlin, and Meisel (1992) warned that "what gets measured gets taught" (p. 12). In discussing the implications of inclusive decision making in testing programs, Yell and Shriner (1996) extended this concern to express that it also may be the case that "who gets measured gets taught" (p. 104). With increased emphasis on goals, standards, and indicators, access to the general curriculum, and inclusion in state and district assessments, the reporting requirements of IDEA validate that, in a very real sense, "what gets reported about whom gets taught or is addressed."

The IDEA addresses the issue of accountability by making data about the results of schooling for students with disabilities very public. Specifically, Sec. 612 requires that the SEA report to the public on the assessment performance of students with disabilities as often and in the same detail as it reports on the performance of nondisabled students. Remember, the new language is intended to be for students with disabilities as a group. The provision does not seek individual student results and, in fact, reports must protect the identity of individual students. Reports will include minimally:

- The number of children participating in general (regular) assessments

- The number of children participating in alternate assessments

- The performance of children with disabilities on general assessments (beginning not later than July 1, 1998) and on the alternate assessment (not later than July 1, 2000). (Sec. 612(a)(17)(B))

There are several additional reporting requirements. Data from all reports related to students with disabilities must be disaggregated for assessments conducted after July 1, 1998. Also, every 2 years the SEA must submit a separate report to the U. S. Department of Education on the progress of students with disabilities toward meeting the performance goals and standards for all students. In addition, Sec. 653, State Improvement Plans, requires that all states include assessment data and comparisons of performance as part of their applications to the federal government for funds. Specifically, information concerning students with disabilities must include:

- Their performance on state assessments and other performance indicators established for all children, including drop-out and graduation rates and postsecondary education and employment.

- How their performance on these indicators compared to that of nondisabled children. (Sec. 653(b))

The IDEA emphasizes that the vast amount of data collected on students with disabilities is to be used to focus change efforts toward attainment of better student results. Although not a specified part of new reports, states also must increase their evaluation of suspension and expulsion rates (Sec. 612(a)(22)). If students with disabilities are determined to represent a disproportionate number of longterm suspensions and expulsions (e.g., compared to students 
without disabilities), the state must review and, if appropriate, revise its policies and procedures for dealing with these issues. Again, accountability for appropriate outcomesthis time of a non-cognitive nature-is the focus of the more prescriptive approach.

\section{DISCIPLINE OF STUDENTS IN SPECIAL EDUCATION}

Another significant addition of the 1997 amendments is a section affecting the discipline of students with disabilities. Congress heard testimony regarding the lack of parity school officials faced when making decisions about disciplining students with and without disabilities who violated the same school rules (Senate Report, 1997). To address these concerns, Congress added a section to the IDEA in an attempt to balance school officials' obligation to ensure that schools are safe and orderly environments conducive to learning and the school's obligation to ensure that students with disabilities receive a free appropriate public education. Section $615(\mathrm{~K})$ covers the discipline of students with disabilities. Figure 1 is a flowchart for disciplining students with disabilities.

\section{Disciplinary Procedures}

School officials may discipline a student with disabilities in the same manner as they discipline students without disabilities - with a few notable exceptions. If necessary, school officials may unilaterally change the placement of a student for disciplinary purposes to an appropriate interim alternative educational setting (IAES), another setting, or by suspending the student to the extent that these disciplinary methods are used with students without disabilities. The primary difference is that with students who have a disability, the suspen-

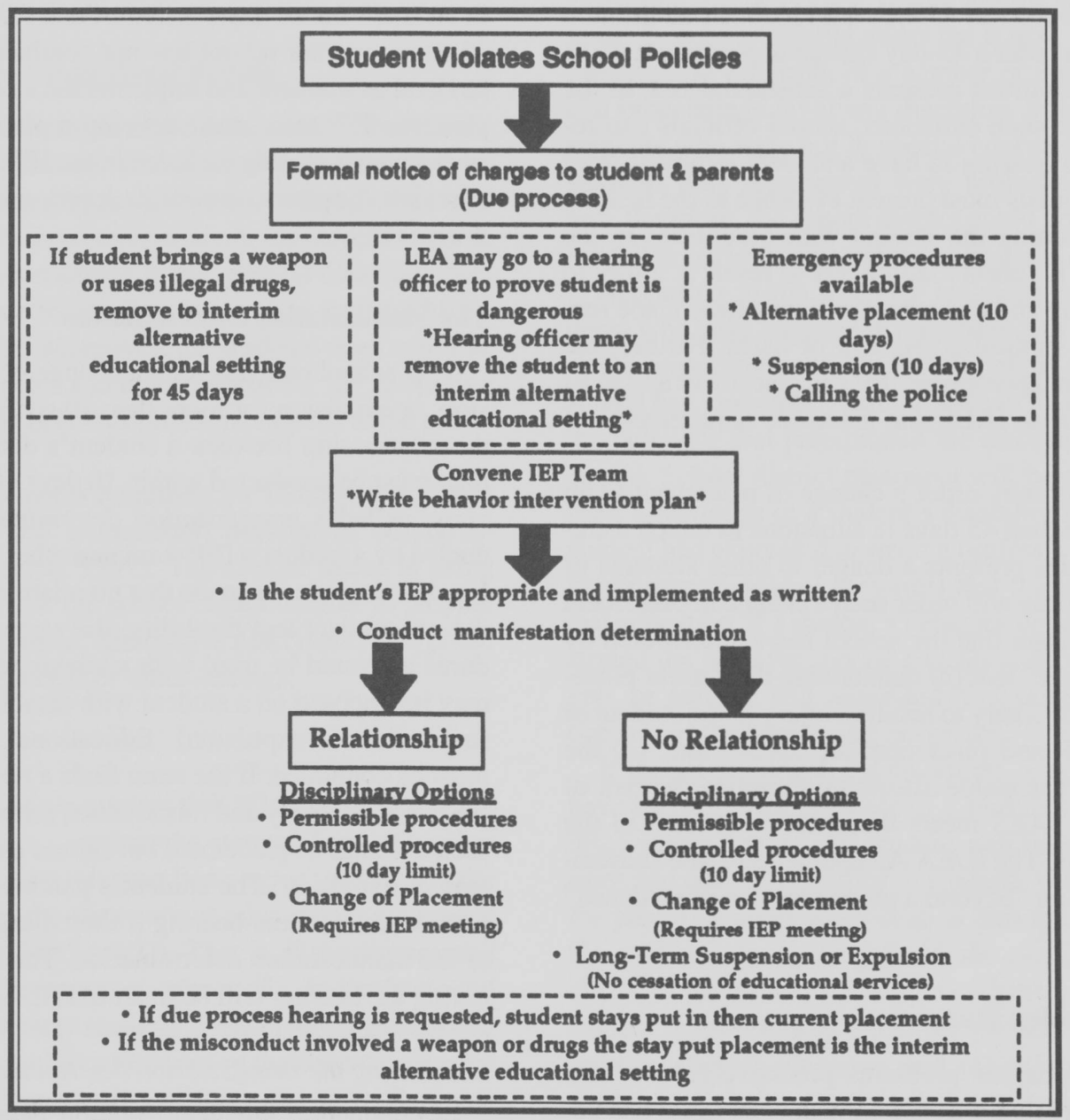

Source: The Law and Special Education, by M.L. Yell (Upper Saddle River, NJ: Prentice Hall/Merrill, in press). Reprinted with permission. 
sion or placement change may not exceed 10 school days.

School officials may place a student with disabilities unilaterally in an appropriate IAES for up to 45 days if the student brings a weapon to school or a school function. For purposes of the IDEA, Congress defines a weapon as

\begin{abstract}
a weapon, device, instrument, material, or substance, animate or inanimate, that is used for, or is readily capable of, causing death or serious bodily injury, except that such term does not include a pocket knife with a blade of less than $21 / 2$ inches in length. (Senate Report, 1997, p. 35)
\end{abstract}

Likewise, schools may remove a student to an IAES if the student knowingly possesses, uses, or sells illegal drugs or sells or solicits the sale of a controlled substance at school or a school function. Controlled substances are drugs, many of which have medicinal uses, that have a high potential for abuse. (For the list of controlled substances see the Controlled Substances Act, 21 U.S.C. § 812(c)). In addition, a hearing officer can order a 45-day change in placement when a student with disabilities presents a substantial risk to the safety of others. In such situations, school officials can request an expedited hearing to have a student removed from school. School officials must present evidence to the hearing officer that maintaining the student with disabilities in the current placement is substantially likely to result in injury to the student or others and that school officials have made reasonable efforts to minimize this risk of harm. Further, the school must have an appropriate IEP and placement and must place the student in an IAES that meets the requirements of the IDEA.

A hearing officer may order a change of placement to an IAES for not more than 45 days in situations in which a student with disabilities presents a danger to other students or staff. A hearing officer will order such a change in placement if he or she determines that the school has demonstrated by "substantial evidence" that (a) maintaining the current placement is substantially likely to result in injury to the student or others, (b) the IEP and placement are appropriate, (c) the school has made reasonable efforts to minimize the risk of harm, and (d) the IAES meets the criteria set forth in the IDEA Amendments. The IDEA Amendments define substantial evidence as being "beyond a preponderance of evidence" (Sec. $615(\mathrm{k})(10)(\mathrm{C}))$.

\section{Behavior Intervention Plan}

To deal with behavior problems proactively, the 1997 amendments require that if a student with disabilities has be- havior problems (regardless of the student's disability category), the IEP team shall consider strategies, including positive behavioral interventions, strategies, and supports, to address these problems. In these situations, a proactive behavior intervention plan, based on functional behavioral assessment, should be included in the student's IEP. The behavior intervention plan for each student should delineate expected behaviors, inappropriate behaviors, and positive and negative consequences. The disciplinary process that will be followed, including intervention techniques, should be outlined in the plan. The plan also should include procedures for dealing with a behavioral crises. Some legal scholars believe that schools will have to include behavior intervention plans in the IEPs of all students with disabilities, and that school districts will have to hire full-time behavior specialists to write these plans (Discipline provisions, 1997).

If a school suspends or places a student with disabilities in an IAES for 10 days, or removes a student to an IAES for 45 days, and the school has not conducted a functional behavioral assessment and implemented a behavior intervention plan, the IEP team must develop a plan within 10 days. If such a plan is already included in the IEP, the team must meet to review the plan to review its appropriateness and modify it if necessary.

\section{The Manifestation Determination}

If school officials seek a change of placement, suspension, or expulsion for more than 10 school days, a review of the relationship between a student's disability and misconduct must be conducted within 10 days of the action. This review, called a manifestation determination, must be conducted by a student's IEP team and other qualified personnel. If a determination is made that no relationship exists between the misconduct and disability, the same disciplinary procedures as would be used with students who are not disabled may be imposed on a student with disabilities (i.e. long-term suspension or expulsion). Educational services, however, must be continued. If the team finds a relationship between a student's disability and misconduct, school officials still may seek a change of placement but cannot use long-term suspension or expulsion. The student's parents may request an expedited due process hearing if they disagree with the results of the manifestation determination. The student's placement during the hearing will be in an IAES.

\section{Conducting the manifestation determination}

In conducting the manifestation determination, the IEP 
team must consider all relevant information regarding the behavior in question. This includes evaluation and diagnostic results, information supplied by the parents, and direct observations of the student. Furthermore, the team must examine the student's current IEP and placement to determine if they are appropriate. The IEP team can determine that the misconduct was not a manifestation of a student's disability only when the following three criteria are met:

1. The student's IEP and placement were appropriate (including the behavior intervention plan) and the IEP was implemented as written;

2. The student's disability did not impair the ability of the student to understand the impact and consequences of the behavior subject to the disciplinary sanction;

3. The student's disability did not impair the student's ability to control the behavior at issue.

\section{Interim Alternative Educational Setting}

The IDEA amendments describe the standards that the interim alternative educational setting must meet. First, the setting must be determined by the IEP team. Although the IAES is not usually in the school environment, the student must be able to continue to participate in the general education curriculum and continue to receive the services and modifications listed in the IEP. Moreover, the students must continue to work toward the goals and objectives of the IEP, including goals that address the behavior problems that led to the placement.

The IDEA requirements regarding the IAES will not limit schools' ability to use homebound placements (Congressional Research Service, 1997). The crucial factor in using these placements is that the school must continue to provide special education services. Alternative placements also could include alternative schools or other settings.

\section{Stay-Put Provision}

The stay-put provision requires that "During the pendency of any proceedings ...., unless the state or local education agency and the parents or guardians agree otherwise, the child shall remain in the then current educational placement (IDEA, 21 U.S.C. $\S 1415$ (e)(3)). That is, if the parents and school personnel disagree on an aspect of a student's special education and either party requests a due process hearing, the child must stay where he or she was at the time the hearing was requested. In Honig v. Doe (1988), the U. S. Supreme Court ruled that the stay-put rule had no exceptions, even in cases in which a student posed a danger to others. Administrators argued that the stay-put rule placed schools in the untenable situation of having to keep potentially dangerous students with disabilities in classrooms (Honig v. Doe, 1988).

In the IDEA Amendments, Congress made some modifications to the stay-put provision in situations involving the discipline of students with disabilities. Administrators may unilaterally remove students who bring weapons or illegal drugs to school or a school function to an IAES for 45 days. If parents or guardians of a student placed in the IAES request a hearing regarding that placement or a manifestation determination, the then current placement is the IAES. Therefore, the student will remain in the IAES during the pendency of his or her hearing.

\section{IDEA Protections for Students Not Yet Eligible for Special Education}

Section $615(\mathrm{k})(8)(\mathrm{A}-\mathrm{C})$ addresses the issue of disciplining students not yet eligible under the IDEA. This issue became important as the result of a number of due process and judicial proceedings involving discipline in which attorneys for students who were not in special education asserted that the students they represented were protected under the IDEA and, therefore, the school district could not expel them without adhering to the procedural safeguards of the law.

According to the statutory language of PL 105-17, students who have engaged in misconduct or rule violation may assert protection under the IDEA only if school district personnel had knowledge that the student had a disability before the behavior that precipitated the disciplinary sanctions occurred. School district personnel will be determined to have prior knowledge of a student's disability if the parents of the student had expressed in writing (unless a parent is illiterate), to appropriate school personnel that the student needed special education, if a student's behavior or performance demonstrated the need for special education services, or if the parents or teacher had requested an evaluation or expressed concern to the appropriate personnel.

If school personnel, did not know, or could not reasonably have known, of the presence of a disability, prior to taking the disciplinary actions, the student will be subject to the same rules and sanctions applied to students without disabilities. If the parents request an evaluation during the period in which the student is being disciplined, the evaluation must be conducted expeditiously. If the school district determines that the student is indeed disabled under the IDEA, the school must provide special education and related services. While the evaluation is being conducted, the student shall remain in the educational placement determined by the school personnel. 


\section{Referral to Law Enforcement and Judicial Authorities}

Schools may report crimes committed by a student in special education to the proper authorities. Furthermore, law enforcement agencies and judicial authorities may exercise their responsibilities with regard to enforcement of federal and state laws. According to Congress, nothing in the IDEA prevents either school officials or law enforcement authorities from discharging their duties in such matters (Senate Report, 1997). Moreover, the school district shall ensure that copies of the special education and disciplinary records of a student in special education be transmitted to the proper authorities when such situations occur.

\section{Cautions in Interpreting the Discipline Requirements}

Many questions have arisen regarding the discipline section of PL 105-17. The statutory language is somewhat ambiguous. This has led some to believe that the new law effectively precludes the discipline of students with disabilities; others have countered that the IDEA Amendments essentially codify case law and will allow schools greater discretion in discipline matters (Discipline provisions, 1997).

A memorandum issued by the Congressional Research Service has helped to clarify matters. The memo stated that the IDEA Amendments essentially codify existing laws developed in court cases and interpreted by the Department of Education. The memo points out that the intent of Congress in drafting the discipline section was to provide more disciplinary flexibility to schools and that the IDEA Amendments, when viewed in their entirety, codify this increased flexibility (Congressional Research Service, 1997). Until the regulations are promulgated and states rewrite their rules and guidelines, the issue will remain unclear; therefore, the opinion of the Congressional Research Service regarding the disciplinary section should be followed.

\section{FURTHER PROCEDURAL SAFEGUARDS}

In special education, procedural safeguards guide the method by which school officials make decisions regarding the education of students, and substantive due process rights identifies those personal rights that school officials may not abridge (Valente, 1994). In writing the IDEA, Congress created explicit procedural safeguards to be afforded students with disabilities and their parents. These safeguards were strengthened in the IDEA Amendments of 1997. The changes in the procedural safeguards are related to the use of mediation depicted in Table 5.

\begin{tabular}{ll} 
& TABLE 5 \\
& IDEA Requirements: \\
Procedural Safeguards, Mediation, Section 615 (e) & \multicolumn{1}{c}{ Explanation } \\
Key Points & - Mediation must be available when- \\
Availability & ever a hearing is requested. \\
Voluntary & Participation by both parties is \\
& voluntary. \\
Hearing delays & - The State may not delay parental \\
& rights to a hearing under IDEA. \\
& - Mediations must be conducted in a \\
Mediators & timely manner. \\
& - The State must provide a list of \\
Explanations & qualified, trained, impartial mediators. \\
& - The LEA or SEA may require parents \\
& who chose not to use mediation to \\
& meet with a disinterested third party \\
& who will explain the benefits of \\
& mediation and encourage its use. \\
Costs & - The State will pay costs of mediation. \\
Agreements & - Agreements will be in writing. \\
Confidentiality & - Discussions will be confidential and \\
& may not be used as evidence in \\
& subsequent hearings. \\
& - Parties may be asked to sign a \\
confidentiality agreement.
\end{tabular}

\section{Mediation}

A much talked about addition to the procedural safeguards of IDEA is that of voluntary mediation of disputes between the school district and the parents of a child with a disability (see Table 5). Mediation is not new. Some states (e.g., Connecticut, Massachusetts) have used it for more than 20 years. Others, such as Delaware and South Carolina, have used it regularly for the past few years. Sec. 615 now requires all states to offer mediation as an initial avenue for conflict resolution while maintaining parents' rights to timely due process. Under Sec. 615 (e), schools and states must make information about mediation available to parents. If the parents refuse mediation, the LEA may, in fact, require them to meet with a disinterested third party to hear explanations of the benefits and usefulness of the process. These representatives likely would be from the Parent Training and Information Centers authorized by Sec. 682, or from other alternative dispute resolution groups. 
States will be required to maintain a listing of trained mediators and will bear the cost of the mediation process. When mediation is used, attorneys may or may not be present. All discussions held in mediation will be treated as confidential and may not be used as evidence in any subsequent actions, including due process hearings and court proceedings. Parents and schools may be asked to sign an agreement of confidentiality before mediation begins.

If the mediation is successful the agreement reached must be put in writing. This requirement seeks to improve the follow-through of agreed-upon plans. The provisions for mediation seek three important outcomes.

First, mediation may enhance both the speed and the quality of decision making regarding programming for students. Even though everyone has the student's best interest in mind, wasted time and poor instruction do no good whatsoever.

Second, burdens on the due process system and litigative activity should be reduced. The committee report emphasizes the hope that what is now observed in states where mediation is often used will be observed in states where it is used less frequently.

Finally, mediation is a potential public relations boon. Amicable dispute resolutions through mediation may serve to increase the use of the process, making it the "normal" course of action while simultaneously reducing negative interactions that capture the general public's eye.

\section{Attorneys' Fees}

The new law retained provisions regarding attorneys' fees and added a few qualifications. Attorneys' fees may be reduced in situations where the attorney representing the parents failed to provide the local education agency with information regarding the specific nature of the parent's dispute. Attorneys must notify school officials in a timely manner of the nature of the problem and any proposed solutions. In addition, because the IEP process should be devoted to students' needs and planning for their education, the IDEA amendments specifically exclude the payment of attorneys' fees for attorney participation in the IEP process. The only exception is when the IEP meeting is ordered in an administrative hearing or court proceeding.

The amendments also specifically adopted the U.S. Supreme Court's Hensley v. Eckerhart (1983) standard for determining the amount of any attorneys' fees to be awarded. In that decision, the high court stated that the basis for determining attorneys' fees should be the extent of a plaintiff's success on the claims. That is, in determining awards, courts are re- quired to assess the extent to which the plaintiffs prevailed on significant issues (Senate Report, 1997). When a plaintiff fails to prevail on significant issues, the hours the attorneys spent on the issue can be excluded from calculation of the fee. Of course, when the plaintiff fails to succeed on any issue brought, no attorneys' fees will be awarded.

\section{SPECIAL EDUCATION IN THE CORRECTIONAL SYSTEM}

The IDEA does not require states to provide special education services to persons aged 18 to 21 who are inmates in an adult prison if they were not receiving special education services prior to their incarceration. If they were receiving services, the obligation to provide services would continue. If a student was identified as eligible under the IDEA but left school prior to incarceration, that student must receive special education services. Essentially, inmates who had an IEP in their last educational placement must continue to receive special education services in the correctional institution. The obligation to provide special education services to youth in juvenile facilities remains unchanged.

\section{PRIVATE SCHOOLS}

A question that has vexed special educators, and has had no clear answer in the IDEA, concerns the extent of the public schools' responsibilities to students with disabilities whose parents enroll them in private schools. Do these students have the same right to special education and related services under IDEA as do students who are attending public school? The IDEA unquestionably extends some benefits to private school students with disabilities; however, the extent of these benefits is unclear.

The IDEA requires that local public school districts placing students with disabilities in private schools must provide special education and related services to these students. Further, case law clearly indicates that if a school district fails to provide an appropriate education to a student with a disability and the parent unilaterally places the child in a private school to receive an appropriate education, the school has to reimburse the parents for private school placement (Burlington School Committee v. Department of Education, 1985).

A more difficult issue arises when students, for whom the school district normally would have been obligated to provide a special education, are placed in a private school directly by their parents. That is, when parents choose a private school placement rather than the public school, including the 
special education services that the public school would have provided, does the public school still have an obligation to provide these services? In these situations, the public school will not be liable for the private school placement if the school's program is appropriate. The school, however, still retains some obligations to the privately placed student derived from its duty under IDEA to provide access to a free appropriate public education (FAPE) to students with disabilities residing within the school district.

The IDEA Amendments indicate that a school district's obligation to students placed in private schools ends once they make a FAPE available, and the parents elect to place the student in a private school. That is, the school district does not have to pay for the private school placement. If, however, a hearing officer or court later determines that a FAPE was not made available to a student by the public school, the officer or judge may order reimbursement to the parents. In these situations, the crucial consideration is whether the special education the school district offered was appropriate to the student's needs and would have allowed the student to make meaningful educational progress.

To recover reimbursement for private school placements four conditions must be met: (a) the student must have been enrolled in the LEA, (b) the parents must have notified the LEA of their intention to enroll the child in a private school, (c) the LEA must not have consented to or referred the child to the private school, and (d) the LEA must have failed to provide a FAPE in a timely manner. The amount of the reimbursement, which normally would be for the full cost of special education and related services, may be reduced if: (a) at the most recent IEP meeting the parents did not inform the LEA that they planned to enroll their child in a private school, (b) the parents did not give notice within 10 days that they rejected the school's placement and intended to enroll their child in a private school, or (c) the parents acted unreasonably in removing their child from the public school and enrolling him or her in a private school.

\section{FUNDING}

Through the IDEA, the federal government provides funding to assist states with special education costs. To receive IDEA funds, states must submit a state special education plan to the U. S. Department of Education. This plan must show that a state is providing free appropriate special education services to all students with disabilities residing in the state between the ages of 3 and 21 in accordance with the procedures set forth in the IDEA. This includes students with disabilities who have been suspended or expelled from school. States that meet the IDEA requirements receive federal funding.

The IDEA funds are received by the state education agency for distribution to the local education agencies. The federal funds do not cover the entire cost of special education but, rather, are intended to provide financial assistance to the states. Congress originally intended to fund $40 \%$ of states' costs in providing special education services through the IDEA. The actual levels of funding to the states, however, have amounted to approximately $6 \%$ to $7 \%$ of total expenditures. The Omnibus Consolidated Appropriations Act Fiscal Year 1997, enacted in 1996, raised the federal contribution to close to $10 \%$.

Federal expenditures are computed on a state-by-state basis in accordance to the number of students with disabilities served, which is referred to as the child count formula. No adjustments are made either for the category of disability or setting in which a student is served. This number is multiplied by $40 \%$ of the average per-student expenditure in public schools in the United States. The federal government caps the number of students in special education in each state that federal sources will fund. States cannot serve more than $12 \%$ of the total number of school-age students in the state.

A major change in funding was included in the 1997 amendments to the IDEA. The funding formula remains based on the child count until federal appropriations reach $\$ 4.9$ billion. Federal appropriations above that level will be allocated according to a population-based formula with an adjustment for poverty rates. When the trigger of $\$ 4.9$ billion is reached, the new formula, based on the state's population (85\%) and poverty level (15\%), will apply to all excess appropriations. Congress capped the total increases a state could receive under this formula as no more than $1.5 \%$ over the increase in federal funding from the previous year. Neither can states receive less than they did in fiscal 1997. The purpose of the caps and floors is to limit the increase in federal funding to states that gain from the formula change and prevent large decreases in states that receive less under the new formula.

The IDEA also requires that $75 \%$ of the federal funds the states receive be directed to the local schools and that $25 \%$ may be used at the state level. Most of the federal funding, therefore, flows from the federal to the state government and, in turn, to the local school districts. To receive state funds, local school districts must have programs that meet the state requirements. States are required to establish management and auditing procedures to ensure that federal funds will be expended in accordance with IDEA. States also must set up systems to allocate 
funds. The amount of flow-through funds given to a local education agency is in proportion to the district's contribution to the state total of students in special education.

The $25 \%$ of the federal funds that may be set aside for state agency activities may be used for administration and supervision, direct and supportive services for students with disabilities, and monitoring and complaint investigation (IDEA Regulations, 34 C.F.R. $\S 300.370$ (a)). States may, however, use only $5 \%$ of the $25 \%$ of federal funds for administrative purposes. The states' administrative activities may include technical assistance to local education agencies administering the state plan, approval and supervision of local activities, and leadership activities and consultative services (IDEA Regulations, 34 C.F.R. $\S 300.621$ ).

The IDEA Amendments of 1997 capped the actual dollar amount of the 5\% that may be used for administrative purposes at the fiscal 1997 level. States also will be given increases equal to the inflation rate or the increase in federal expenditures, whichever is less. If inflation is lower than the percentage increase in federal appropriations, states are required to spend the difference on improvements in services to students with disabilities.

\section{ADDITIONAL CHANGES TO THE IDEA}

In this article we have explained some of the more significant changes to the IDEA. Other changes that will have a significant affect on special education have not been addressed here. Some of these changes are included in Table 6.

\section{INITIAL IMPLICATIONS FOR TEACHERS, ADMINISTRATORS, AND TEACHER TRAINERS}

We wish to point out that many schools and professionals around the country are providing many of the "best practices" now part of the IDEA. Still, the Amendments will lead to changes in the manner in which students with disabilities are served in public education. The final form the changes will take have yet to be determined. Regulations implementing the IDEA Amendments of 1997 have to be written by the Department of Education, and many states will have to make changes to their laws to bring them into compliance with the IDEA. These regulations will clarify the role changes that will be necessary. In addition, court cases will help to clarify those areas of the law that remain unclear. Nevertheless, the roles of administrators and general and special educators in the education of students with disabilities will be expanded and altered as the amendments and regulations are enacted.

\section{TABLE 6}

IDEA Requirements: Additional Changes

\begin{tabular}{|c|c|}
\hline Key Points & Explanation \\
\hline At-risk students & $\begin{array}{l}\text { - SEAs now may serve 3- to 9-year- } \\
\text { olds at risk or developmentally de- } \\
\text { layed. }\end{array}$ \\
\hline $\begin{array}{l}\text { Infants and } \\
\text { toddlers with } \\
\text { disabilities }\end{array}$ & $\begin{array}{l}\text { - Part } \mathrm{C} \text { emphasizes serving infants } \\
\text { and toddlers in natural environments. }\end{array}$ \\
\hline Related services & $\begin{array}{l}\text { - Orientation and mobility are added as } \\
\text { a new category of related services. }\end{array}$ \\
\hline Regulations & $\begin{array}{l}\text { - Limits the authority of the Secretary } \\
\text { of Education to promulgate regula- } \\
\text { tions and specifies new procedures } \\
\text { for promulgating regulations. }\end{array}$ \\
\hline Charter schools & $\begin{array}{l}\text { When charter schools are within an } \\
\text { LEA, the LEA must serve students } \\
\text { with disabilities attending the } \\
\text { charter school. }\end{array}$ \\
\hline $\begin{array}{l}\text { Terminology } \\
\text { change }\end{array}$ & $\begin{array}{l}\text { "Serious emotional disturbance" is } \\
\text { referred to in the law as "emotional } \\
\text { disturbance." The change is intended } \\
\text { to eliminate the pejorative connota- } \\
\text { tion of the term "serious" and is } \\
\text { intended to have no substantive or } \\
\text { legal significance. }\end{array}$ \\
\hline \multirow[t]{2}{*}{$\begin{array}{l}\text { Personnel } \\
\text { standards }\end{array}$} & $\begin{array}{l}\text { Paraprofessionals and assistants } \\
\text { must be trained appropriately and } \\
\text { supervised in accordance with } \\
\text { state law. }\end{array}$ \\
\hline & $\begin{array}{l}\text { - SEAs may adopt a policy that } \\
\text { includes the requirement that LEAs } \\
\text { make an ongoing good-faith effort to } \\
\text { recruit and hire appropriately trained } \\
\text { personnel. }\end{array}$ \\
\hline Methodology & $\begin{array}{l}\text { - While teaching methodologies are } \\
\text { appropriate subjects for discussion } \\
\text { and consideration by an IEP team, } \\
\text { they are not expected to be written } \\
\text { into the IEP. }\end{array}$ \\
\hline Hearing rights & $\begin{array}{l}\text { - Parents may, at their option, require } \\
\text { an electronic verbatim recording of a } \\
\text { hearing. }\end{array}$ \\
\hline $\begin{array}{l}\text { Prior written } \\
\text { notice }\end{array}$ & $\begin{array}{l}\text { - LEAs must include in notifications to } \\
\text { parents sources they may contact } \\
\text { to obtain assistance in understanding } \\
\text { procedural safeguards. }\end{array}$ \\
\hline to & - Parents can review all records. \\
\hline
\end{tabular}




\section{Teachers}

The IDEA places a much greater emphasis on student participation in the general education curriculum. The IEP, thus, is reconceptualized as a broader document encompassing student goals and objectives for general education and special education. The location of supplementary services to make the general curriculum accessible is a new requirement of Sec. 614(d)(1)(A)(vi). During IEP planning, participants will need to consider when and where instruction in the general curriculum will take place. We are used to the idea that special education services may be provided in the general education setting. It may be the case that the more appropriate location of instruction in the general curriculum is a special education setting. The extent to which the new IDEA has anticipated the impact of this contingency is not clear.

Regardless of where the education of a student occurs, the language of the IDEA consistently reinforces the intent of Congress to require the IEP to focus on how the student's needs resulting from his or her disability can be addressed so the student can participate, at the individually appropriate level and in the appropriate place in the general curriculum offered to all students (Senate Report, 1997). A more collaborative relationship between general educators and special educators is likely to be needed. Planning, implementing, and evaluating instructional programs will necessitate more frequent communication across disciplines than is sometimes found in today's schools.

\section{Administrators}

Administrators will have more discretion in disciplining students in special education. They may suspend a student with disabilities unilaterally for up to 10 school days. Further, in situations involving students with disabilities bringing weapons, using, possessing, or selling drugs, or selling a controlled substance at school or a school function, administrators may unilaterally remove the student in an IAES for up to 45 days. In writing a behavior intervention plan, in conducting a manifestation determination, or in situations involving long-term suspension or expulsion, however, administrators cannot act unilaterally. In these situations the IEP team must be involved.

\section{Teacher Trainers}

Special educators must receive more professional development and training activities so they can support and deliver instruction in the general curriculum. Few special education teachers are prepared adequately to teach content areas, yet they are not exempt from the responsibility to know the content of standards-oriented curricula (National Center on Educational Outcomes, 1996). Indeed, CEC foresees its professional development activities expanding in this and other areas to meet the demands of the reauthorization requirements (Council for Exceptional Children, 1997).

General education teachers will be more involved in the IEP process. Teacher preparation programs for general educators, therefore, should include preparations (i.e. special education courses) to help them assume their expanded roles.

Special educators will require in-depth training in writing legally correct goals and objectives. Further, the preparation should emphasize formative evaluation procedures for monitoring student progress toward these goals and objectives.

If a student has a history of behavior problems, the IEP must contain a behavioral intervention plan. Therefore, special education teachers and other professionals involved in the assessment process (e.g., school psychologists) must be trained in functional behavioral assessment and the principles and procedures of applied behavior analysis. Moreover, the IDEA's increased emphasis on assistive technology will necessitate teachers being prepared in the application of technologies such as augmentative communication and computer applications to education.

\section{CONCLUSION}

The IDEA Amendments of 1997 will require immediate and long-term changes in the way we educate students with disabilities. The majority of changes in this article took effect when President Clinton signed the law (June 4, 1997). For example, the changes involving the discipline of students with disabilities are now law. Modifications to the IEP, however, will not take effect until July 1, 1998. Readers are cautioned that the final form these changes will take is uncertain because the regulations implementing the IDEA Amendments of 1997 have yet to be promulgated by the U. S. Department of Education. Current plans call for these regulations to be in place by the fall of 1998.

In addition, states will have to bring their rules and guidelines into conformity with the new law as well as the regulations. The meaning of the changes in the IDEA no doubt will be clarified further by the courts. Nevertheless, these changes portend significant alterations in the roles of special and general educators, administrators, and teacher trainers. 


\section{REFERENCES}

American Federation of Teachers (1996). Making standards matter: 1996. Washington, DC: Author.

Burlington School Committee of the Town of Burlington v. Department of Education of Massachusetts, 471 U.S. 359 (1985).

Clymer, A. (1997, May 14). House passes bill for disabled that adds education resources. New York Times, pp. A1, A17.

Council for Exceptional Children. (1997, June). IDEA sails through congress! CEC Today, 3(10), 1, 9, 15.

Deno, S. L. (1992). The nature and development of curriculum-measurement. Preventing School Failure, 36, 5-11.

Discipline provisions in new IDEA cause serious concerns. Special Educator, 12, (June 6, 1997), p. 1 \& 4.

Erikson, R., Thurlow, M. L., Thor, K., \& Seyfarth, A. (1996). 1995 state special education outcomes. Minneapolis: University of Minnesota, National Center on Educational Outcomes.

Frey, W. D., \& Lynch, L. (1992). Using exit performance assessments to evaluate and improve programs for students with educable mental impairment and students with emotional impairments. Lansing, MI: Disability Research Systems.

Hensley v. Eckerhart, 461 U.S. 424 (1983).

Honig v. Doe, 479 U.S. 1084 (1988).

Individuals with Disabilities Education Act Regulations, 34 C. F. R. Parts 300 and 301. (1992). Appendix C to Part 300: Notice of Interpretation. 57 Fed. Reg. 44839.

Individuals with Disabilities Education Act of 1990, 20 U.S.C. $\S$ 1401-1485.

Individuals with Disabilities Education Act Amendments of 1997 , P.L. 105-17, 105th Congress, 1st session.

Johnson, Nancy. (May 30, 1997) Memorandum from the Virginia School Boards Association concerning the discipline provisions in H.R. 5 and S. 717, 105th Congress to Congressional Research Service. Unpublished document.

Kentucky Department of Education. (1992). KIRIS: Kentucky alternate portfolio project-Teacher's guide. Frankfort: Kentucky Systems Change Project, Author.

Leone, P. E., McLaughlin, M. J., \& Meisel, S., M. (1992). School reform and adolescents with behavioral disorders. Focus on Exceptional Children, 25(1), 1-15.

Maryland State Department of Education. (1995). Independence mastery assessment program: IMAP PILOT. Baltimore: Author.

McLaughlin, M. J., \& Warren, S. H. (1995). Individualized education programs: Issues and options for change. College Park,
MD: University of Maryland, Center for Policy Options in Special Education.

National Center on Educational Outcomes. (1996, February). Focus group feedback on the National Science Standards to the National Committee on Science Education Standards and Assessments. Minneapolis: University of Minnesota.

Omnibus Consolidated Appropriations Act, FY97, Senate Joint Resolution, N. 63, 104th Congress, 2nd session, Congressional Record, S12327 (1996).

Schrag, J. A. (1996). The IEP: Benefits, challenges, and directions. Alexandria, VA: Report of Project Forum, National Association of State directors of Special Education.

Senate Report of the Individuals with Disabilities Act Amendments of 1997, available at wais.access.gpo.gov.

Shriner, J.G., Gilman, C. J., Thurlow, M. L., \& Ysseldyke, J. E. (1995). Trends in state assessment of educational reforms. $\mathrm{Di}$ agnostique, 20, 101-119.

Shriner, J. G. \& Spicuzza, R. J. (1995). Procedural considerations in the assessment of students at risk for school failure. Preventing School Failure, 39, (2), 33-39.

Shriner, J. G., Thurlow, M. L., \& Ysseldyke, J. E. (1994). Standards for all American students. Focus on Exceptional Children 26(5), 1-19.

Taylor, R. L. (1997). Assessment of exceptional learners (4th ed.). Boston: Allyn \& Bacon.

Thurlow, M., Scott, D., \& Ysseldyke, J. (1995). A compilation of states' guidelines for accommodations in assessments for students with disabilities (Synthesis Report 18). Minneapolis: University of Minnesota, National Center on Educational Outcomes.

Valente, R. (1994). Law in the schools (3d ed.). New York: Merrill.

Yell, M. L., \& Shriner, J. G. (1996). Inclusive education: Legal and policy implications. Preventing School Failure, 40(3), 101-108.

Ysseldyke, J. E., Olsen, K., \& Thurlow, M. L. (1997). Issues and considerations in alternate assessments. Minneapolis: University of Minnesota, National Center on Educational Outcomes.

The IDEA Amendments of 1997 are available on the Education Administration Online homepage on the World Wide Web. The URL is http://www.lrp.com/ed/

Additional information is available from The Council for Exceptional Children at: http://www.cec.sped.org/pp-menu.htm

\section{PERMISSIONS AND COPYRIGHT}

All rights are reserved. No part of this publication may be reproduced, photocopied, faxed, stored in a retrieval system, or transmitted, in any form or by any means, electronic, mechanical, recording or otherwise, without the prior written permission of the publisher.
Back issues are available for sale. Reproduction requires permission and payment of fees. It is illegal and a violation of federal copyright law to reproduce this publication without permission. Direct all inquiries to the permissions editor. 


\title{
NEW 1998 EDITION
}

\section{Free Appropriate Public Education: The Law and Children with Disabilities-Fifth Edition}

\author{
H. Rutherford Turnbull, University of Kansas \\ Ann Turnbull, University of Kansas
}

This definitive resource covers

legislation, case law techniques, due process, parent participation, and much more. The text is completely updated and contains all the substantial amendments made by the 1997 reauthorization of IDEA. The book also reports the pre-1997 provisions of IDEA so that comparisons to the current law can be made. The cases presented in this edition represent those that are widely regarded as "leading" or those that are quite recent and represent an established body of law. By being selective, this text focuses on the most important special education law cases and gives detailed analysis of the court's decisions.

\section{Special Features}

- Completely updated with amendments made by 1997 reauthorization of IDEA

- Detailed analysis of most important cases affecting special education law

- Presents significant pre-1997 provisions of IDEA

- Glossary to explain legal terminology

\section{Contents}

1. Introduction to the American Legal System

2. Federal Policy and Disability

3. Zero Reject

4. Testing, Classification, and Placement

5. Appropriate Education
6. Least Restrictive Appropriate Educational Placement

7. Procedural Due Process

8. Parent Participation and Shared Decision Making

9. Compliance Through the Courts

10. Enforcement of Six Principles and Systems-Change for School Reform

9801/Hardback/448 Pages/ISBN: 0-89108-258-1/\$52.00

Publication Date: December, 1997

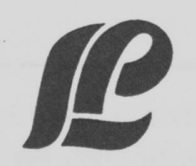

\section{LOVE PUBLISHING COMPANY}

P.O. Box 22353

Denver, CO 80222

303-757-2579 • Fax 303-782-5683 